\title{
CONSOLIDATION OF THE ACTIVITIES OF REGULATORY INSTITUTIONS WHILE IMPLEMENTING E-GOVERNMENT SOLUTIONS
}

\author{
Vida DAVIDAVIČIENE் ${ }^{\circledR}$, Jurgita RAUDELIŪNIENE ${ }^{*}$, \\ Elena VENGRIENĖ, Artūras JAKUBAVIČIUS ${ }^{(1)}$ \\ Department of Business Technologies and Entrepreneurship, \\ Vilnius Gediminas Technical University, Vilnius, Lithuania
}

Received 09 May 2018; accepted 30 August 2018

\begin{abstract}
In the context of globalization, information technology development and transformation not only the needs of the society are changing, structural changes are taking place in the management of the activities of the regulatory institutions as well, because their main function is to meet the changing needs of society. While this process is happening, it becomes difficult to balance activities of the regulatory institutions with the needs of the society and business. This is why optimization of the regulatory institutions functions is one the European Union's priorities. One of the most efficient ways to increase the quality of public services, reduce expenses, encourage cooperation between institutions and make decision making process more efficiently is to create an evaluation system that allows assessment of the efficiency of the consolidation of regulatory institutions functions during the implementation of e-government. In order to solve issues, the analysis of scientific literature, multiple criteria and expert evaluation were applied. The proposed system for evaluation of the consolidation of the activities of the regulatory institutions while implementing solutions of e-government allows complete assessment of the factors and criteria, identification of drawbacks of the process and also enables to create decisions for solutions of the problems.
\end{abstract}

Keywords: activities of regulatory institutions, consolidation, e-government, evaluation.

JEL Classification: M00, M1, M15.

\section{Introduction}

In the context of globalization and transformation an all-encompassing approach to the activities of regulatory institutions and to the implementation of information technologies is necessary, with emphasis on the new tendencies and decisions oriented toward balancing the needs of the regulatory institutions, society and business in the field of regulation. In this research for the solution of this type of issues we propose concentrating on the regulatory

*Corresponding author. E-mail: jurgita.raudeliuniene@vgtu.lt 
institutions' consolidation aspect, in this research it is defined as uniting regulatory institutions for common goals in order to work beneficially for the society and business entities.

Problems that regulatory institutions face when implementing e-government solutions are analyzed by many researchers (Baldwin \& Black, 2008, 2016; Baldwin, Black, \& O'Leary, 2014; Blanc, 2013; Blendinger \& Michalski, 2018; Carroll \& Head, 2010; Cheng, 2014; Choudrie, Zamani, Umeoji, \& Emmanuel, 2017; Christiansson, Axelsson, \& Melin, 2015; Cledou, Estevez, \& Soares Barbosa, 2018; Gil-Garcia, 2012; Hampton, 2005; Juell-Skielse, Lönn, \& Päivärinta, 2017; Layfield, 2014; Luna-Reyes, Picazo-Vela, Luna, \& Gil-Garcia, 2016; Maegli \& Jaag, 2013; Maegli, Jaag, Koller, \& Trinkner, 2011; Maume, 2013; Miyazaki, 2018a, 2018 b), who address such aspects as the needs of the society and business enterprises and the challenges and possibilities of meeting those needs, innovations of information systems and technologies, their implementations and impact on increasing e-government's efficiency, regulatory reforms and processes, the best regulatory practices and possibilities to apply them. Researchers pay quite a lot of attention to the analysis of the methods of evaluation of the public sector institutions' efficiency, however, there is not enough of all-encompassing scientific research and solutions regarding the assessment of the regulatory institutions' consolidation while implementing e-government solutions. Therefore the issue of the assessment of the regulatory institutions' consolidation while implementing e-government solutions remains topical from both scientific and practical point of view with the non-certainty aspect that exists in the dynamic environment, when it is particularly important to create wellgrounded solutions in order to increase functions' efficiency.

In order to solve the issues mentioned above the purpose of the research was formulated: to come up with an evaluation system that would allow assessment of the efficiency of the consolidation of regulatory institutions' activities while implementing e-government solutions. In order to fulfill the purpose, the following methods were applied: literature analysis, multiple criteria evaluation and expert evaluation (structured survey). The proposed evaluation system was prepared using the AHP method, hierarchic classification, calculation of the particular value (Eigenvalue), compatibility index and others. The research data was processed using the SCB tool for the evaluation of the AHP method, when it was applied for approbation of evaluations of two experts of different levels.

The proposed system for evaluation of the efficiency of the consolidation of regulatory institutions' activities while implementing e-government solutions allows us to see how important particular factors are in every case analyzed, to assess the pros and cons, create a number of solutions for the problems identified and to increase the efficiency of the regulatory institutions' activities. To verify the evaluation system an expert research was carried out, it was based on the hierarchical classification of factors, during the research institutions operating in Lithuania and supposition regarding their consolidation were analyzed and an experiment was conducted.

\section{Literature review}

In order to assess the efficiency of the factors that influence the consolidation of regulatory institutions' activities while implementing e-government solutions, analysis of scientific 
literature was conducted, as well as analysis of the environment of the regulatory institutions operating in Lithuania and in the European Union and analysis of the Lithuanian case of institutions that provide care, moreover, 35 primary evaluation factors were identified: cooperation, legal base optimization, accountability, purposefulness, efficiency of the regulatory means, institutions' annual budget, salaries and consultancy fees, number of employees, number of active subjects in the public sector, consolidation of institutions, function consolidation, coordination expenses, information consistency, segment, e-segment, frequency of the service use, service costs, maintenance work informational systems, document management systems, specific systems not related to maintenance, work automatization systems, permits and licenses accounting systems, electronic services systems, operational information management, knowledge-based information system, risk evaluation and management information, time, trust, consultancy, competitiveness, administrative expenses, adaptability of operations to regulatory changes, consultation, training and certification expenses, register management information systems stipulated by law, and laboratory research administration system (Alcaide-Muñoz, Rodríguez-Bolívar, Cobo, \& Herrera-Viedma, 2017; Anthopoulos, Reddick, Giannakidou, \& Mavridis, 2016; Baldwin \& Black, 2008, 2016; Baldwin et al., 2014; Benz \& Eberlein, 1999; Blockmans, Hoevenaars, Schout, \& Wiersma, 2014; Boer, Arendsen, \& Pieterson, 2016; Boer, Pieterson, Arendsen, \& Dijk, 2017; Choi, Park, \& Rho, 2017; Foremny, Sacchi, \& Salotti, 2017; González, Perelman, \& Trujillo, 2009; Hampton, 2005; Janssen \& Voort, 2016; Kersbergen \& Waarden, 2004; Klievink, Bharosa, \& Tan, 2016; Larsson \& Grönlund, 2016; Mohan \& Parthasarathy, 2016; Mueller, 2003; Navarro-Galera, Alcaraz-Quiles, \& Ortiz-Rodríguez, 2016; Scupola \& Zanfei, 2016).

The main factors that influence the model of the consolidation of regulatory institutions' activities while implementing e-government solutions are separated into two levels: the regulatory institutions level and the business entities level. The factors of the regulatory institutions level, as well as the factors of the business entities' level fall into four groups according to the spheres of influence of those factors: regulatory processes, expenses, electronic services provision and information and communication means' evaluation levels (AlcaideMuñoz et al., 2017; Anthopoulos et al., 2016; Baldwin \& Black, 2008, 2016; Baldwin et al., 2014; Benz \& Eberlein, 1999; Blockmans et al., 2014; Boer et al., 2016, 2017; Cheng, 2014; Choi et al., 2017; Choudrie et al., 2017; Christiansson et al., 2015; González et al., 2009; Hampton, 2005; Janssen \& Voort, 2016; Juell-Skielse et al., 2017; Kersbergen \& Waarden, 2004; Klievink et al., 2016; Larsson \& Grönlund, 2016; Luna-Reyes et al., 2016; Mohan \& Parthasarathy, 2016; Mueller, 2003; Navarro-Galera et al., 2016; Scupola \& Zanfei, 2016). The first group is the regulatory processes group that encompasses the factors related to the regulatory processes and exercise influence on the regulatory activities. The second group of factors is the expenses group that encompasses factors related to the expenses of the regulatory process and the expenses obtained by business entities. The third group is the group of factors that define the provision of electronic services. The fourth group of factors is the group of information and communications technology tools that are employed to improve the regulatory process.

In the group of regulatory factors it is demonstrated which factors of the regulatory institutions' level have an influence on the subjects of the business entities level. Majority of 
the factors that influence the efficiency of the regulatory institutions are directly related to the needs of business entities (Table 1).

Table 1. Regulation process factors (created by the authors)

\begin{tabular}{|l|c|c|c|c|c|c|}
\hline \multicolumn{1}{|c|}{ Factor } & $\begin{array}{c}\text { L2R.1. } \\
\text { Time }\end{array}$ & $\begin{array}{c}\text { L2R.2. } \\
\text { Trust }\end{array}$ & $\begin{array}{c}\text { L2R.3. } \\
\text { Consulta- } \\
\text { tion }\end{array}$ & $\begin{array}{c}\text { L2R.4. } \\
\text { Competi- } \\
\text { tiveness }\end{array}$ & $\begin{array}{c}\text { L2R.5. } \\
\text { Optimiza- } \\
\text { tion of the } \\
\text { legal base }\end{array}$ & $\begin{array}{c}\text { L2R.6. } \\
\text { Purpose- } \\
\text { fulness }\end{array}$ \\
\hline L1R.1. Cooperation & + & + & + & & & + \\
\hline $\begin{array}{l}\text { L1R.2. Optimization of } \\
\text { the legal base }\end{array}$ & & + & + & + & $\mathrm{X}$ & + \\
\hline L1R.3. Accountability & & + & & + & & + \\
\hline L1R.4. Purposefulness & + & + & & + & & $\mathrm{X}$ \\
\hline L1R.5. Efficiency & + & + & & + & & + \\
\hline
\end{tabular}

The cost process factors' group demonstrates which factors of the regulatory institutions' level have an impact on the factors of the business entities' level. A large part of the factors that influence expenses that are important to the regulatory institutions do not exercise any influence on the needs of business entities. This means that the increase of expenses to the regulatory institutions brings no benefits to business entities, even the opposite - their expenses of regulatory process administration grow (Table 2).

Table 2. Expenses process factors (created by the authors)

\begin{tabular}{|l|c|c|c|c|c|}
\hline \multicolumn{1}{|c|}{ Factors } & $\begin{array}{c}\text { L2K.1. } \\
\text { Coordina- } \\
\text { tion ex- } \\
\text { penses }\end{array}$ & $\begin{array}{c}\text { L2K.2. } \\
\text { Admin- } \\
\text { istrative } \\
\text { expenses }\end{array}$ & $\begin{array}{c}\text { L2K.3. } \\
\text { Activity's } \\
\text { adapta- } \\
\text { tion to the } \\
\text { changes in } \\
\text { regulation. }\end{array}$ & $\begin{array}{c}\text { L2K.4. } \\
\text { Consulta- } \\
\text { tion, train- } \\
\text { ing and } \\
\text { certification } \\
\text { expenses }\end{array}$ & $\begin{array}{c}\text { L2K.5. } \\
\text { Functions' } \\
\text { consolida- } \\
\text { tion }\end{array}$ \\
\hline $\begin{array}{l}\text { L1K.1. Annual budget of } \\
\text { institutions }\end{array}$ & & & & & + \\
\hline $\begin{array}{l}\text { L1K.2. Salaries and consulta- } \\
\text { tion fees }\end{array}$ & + & + & & & + \\
\hline L1K.3. Number of employees & + & + & & & + \\
\hline $\begin{array}{l}\text { L1K.4. Number of active } \\
\text { subjects in the public sector }\end{array}$ & + & + & & & + \\
\hline $\begin{array}{l}\text { L1K.5. Consolidation of } \\
\text { institutions }\end{array}$ & + & + & & & + \\
\hline $\begin{array}{l}\text { L1K.6. Consolidation of } \\
\text { functions }\end{array}$ & + & & & \\
\hline L1K.7. Coordination expenses & + & & & + \\
\hline
\end{tabular}


The factors that influence the provision of electronic services are directly related with both the regulatory institutions' needs, and the needs of business entities. The major difference is that when the regulatory institutions provide electronic services it is important to define the segment that uses the services and to define the number of those who receive the electronic services, whereas business wants to receive the required service regardless of how many business entities share the same needs.

Table 3. Classification of factors on regulatory institutions' level (created by the authors)

\begin{tabular}{|c|c|c|}
\hline Factors' group & $\begin{array}{c}\text { Primary factors of } \\
\text { evaluation }\end{array}$ & Factor shaping operational qualities \\
\hline \multirow{5}{*}{$\begin{array}{l}\text { L1R. Regulatory } \\
\text { process }\end{array}$} & L1R.1. Cooperation & $\begin{array}{l}\text { Regulatory process must be mutual and different lev- } \\
\text { els and institutions must work together. Institutions } \\
\text { should communicate with other regulatory institu- } \\
\text { tions on all levels and ensure accessibility to users. }\end{array}$ \\
\hline & $\begin{array}{l}\text { L1R.2. Optimization of } \\
\text { the legal base }\end{array}$ & $\begin{array}{l}\text { Abolish, simplify, merge legal acts or informational } \\
\text { commitments or improve their regulation. }\end{array}$ \\
\hline & L1R.3. Accountability & $\begin{array}{l}\text { Institutions must explain and accept their responsibil- } \\
\text { ity for their activities and participate in developing } \\
\text { inter-institutional processes, making sure there is } \\
\text { enough clear explanation and responsibility. }\end{array}$ \\
\hline & L1R.4. Purposefulness & $\begin{array}{l}\text { Research the risk evaluation efficiency possibilities, } \\
\text { optimize the amount of data submitted. }\end{array}$ \\
\hline & L1R.5. Efficiency & $\begin{array}{l}\text { Regulatory means must be relevant to the current } \\
\text { risk, costs must be identified and reduced as much as } \\
\text { possible. }\end{array}$ \\
\hline \multirow{7}{*}{ L1K. Expenses } & $\begin{array}{l}\text { L1K.1. Annual budget } \\
\text { of institutions }\end{array}$ & $\begin{array}{l}\text { Expenses and the annual budget of institutions due to } \\
\text { maintenance institutions' standard operations must } \\
\text { be reduced. }\end{array}$ \\
\hline & $\begin{array}{l}\text { L1K.2. Salaries and con- } \\
\text { sultation fees }\end{array}$ & $\begin{array}{l}\text { Salaries and consultation fees during monitoring pro- } \\
\text { cess must be reduced. }\end{array}$ \\
\hline & $\begin{array}{l}\text { L1K.3. Number of em- } \\
\text { ployees }\end{array}$ & $\begin{array}{l}\text { Expenses for staff, when supervisory institutions } \\
\text { gather repetitive information from business entities } \\
\text { and perform repetitive monitoring actions must be } \\
\text { reduced. }\end{array}$ \\
\hline & $\begin{array}{l}\text { L1K.4. Number of ac- } \\
\text { tive subjects in the pub- } \\
\text { lic sector }\end{array}$ & $\begin{array}{l}\text { Expenses of coordination and monitoring functions } \\
\text { when supervisory institutions gather repetitive infor- } \\
\text { mation from business entities and perform repetitive } \\
\text { monitoring actions must be reduced. }\end{array}$ \\
\hline & $\begin{array}{l}\text { L1K.5. Institutional } \\
\text { consolidation }\end{array}$ & $\begin{array}{l}\text { The costs of regulations must be identified and a } \\
\text { model to reduce them must be defined. Consolidation } \\
\text { of institutions that work in related fields affect the } \\
\text { efficiency of their regulatory process. }\end{array}$ \\
\hline & $\begin{array}{l}\text { L1K.6. Functional con- } \\
\text { solidation }\end{array}$ & $\begin{array}{l}\text { Processes of regulatory institutions identified and } \\
\text { means to carry them out more efficiently proposed. }\end{array}$ \\
\hline & $\begin{array}{l}\text { L1K.7. Coordination } \\
\text { costs }\end{array}$ & $\begin{array}{l}\text { Coordination expenses of institutions when more } \\
\text { than one institution participates in the regulatory } \\
\text { process. }\end{array}$ \\
\hline
\end{tabular}


End of Table 3

\begin{tabular}{|c|c|c|}
\hline Factors' group & $\begin{array}{l}\text { Primary factors of } \\
\text { evaluation }\end{array}$ & Factor shaping operational qualities \\
\hline \multirow{5}{*}{ L1E. E-services } & $\begin{array}{l}\text { L1E.1. Information } \\
\text { consistency }\end{array}$ & $\begin{array}{l}\text { Impact on the population, businesses and government } \\
\text { via e-services or informational system. }\end{array}$ \\
\hline & L1E.2. Segment & Size of the segment that uses the service. \\
\hline & L1E.3. E-segment & Part of the segment that has access to the e-service. \\
\hline & $\begin{array}{l}\text { L1E.4. Frequency of } \\
\text { the service use }\end{array}$ & Number of service uses per given period. \\
\hline & L1E.5. Service cost & $\begin{array}{l}\text { The change in service provision and reception cost } \\
\text { after its digitalization. }\end{array}$ \\
\hline \multirow{11}{*}{$\begin{array}{l}\text { L1I. Information } \\
\text { and communica- } \\
\text { tions technology } \\
\text { tools }\end{array}$} & $\begin{array}{l}\text { L1I.1. Maintenance } \\
\text { work informational } \\
\text { systems }\end{array}$ & $\begin{array}{l}\text { Preparation of annual and operative inspection plans } \\
\text { and preparation of inspection schedules, carrying } \\
\text { out the inspection, carrying out appeal procedures, } \\
\text { fine implementation and control. Data exchange with } \\
\text { other supervisory institutions. }\end{array}$ \\
\hline & $\begin{array}{l}\text { L1I.2. Specific work } \\
\text { automatization systems } \\
\text { not related to mainte- } \\
\text { nance }\end{array}$ & Preparation for inspection and information collection. \\
\hline & $\begin{array}{l}\text { L1I.3. Register manage- } \\
\text { ment information sys- } \\
\text { tems stipulated by law }\end{array}$ & Evaluation of the risk level of the controlled objects. \\
\hline & $\begin{array}{l}\text { L1I.4. Document man- } \\
\text { agement systems }\end{array}$ & $\begin{array}{l}\text { Collection of data required for the maintenance pro- } \\
\text { cess from business subjects and survey conduction. }\end{array}$ \\
\hline & $\begin{array}{l}\text { L1I.5. Permits and } \\
\text { licenses accounting } \\
\text { systems }\end{array}$ & $\begin{array}{l}\text { Issuing of permits and licenses, administration of } \\
\text { related data, accounting of the tax for the documents } \\
\text { issued. }\end{array}$ \\
\hline & $\begin{array}{l}\text { L1I.6. E-services pro- } \\
\text { vision informational } \\
\text { systems }\end{array}$ & $\begin{array}{l}\text { To help simplify citizens' participation in approving } \\
\text { new rules and standards by explaining to them official } \\
\text { obligations and procedures. Informing businesses } \\
\text { about future inspections, submitting the material and } \\
\text { questionnaires currently in possession, consultations. }\end{array}$ \\
\hline & $\begin{array}{l}\text { L1I.7. Management of } \\
\text { the operational infor- } \\
\text { mation }\end{array}$ & $\begin{array}{l}\text { Data analysis, report preparation, monitoring of the } \\
\text { implementation of the activity's indicators. }\end{array}$ \\
\hline & $\begin{array}{l}\text { L1I.8. Knowledge-based } \\
\text { information system }\end{array}$ & $\begin{array}{l}\text { Make public legal acts, compile information bases } \\
\text { provide clear and systematic information and instruc- } \\
\text { tions that would be easily accessible to business enti- } \\
\text { ties. }\end{array}$ \\
\hline & $\begin{array}{l}\text { L1I.9. Risk management } \\
\text { and evaluation informa- } \\
\text { tional systems }\end{array}$ & Evaluation of the risk level of the controlled objects. \\
\hline & $\begin{array}{l}\text { L1I.10. Laboratory re- } \\
\text { search administration } \\
\text { systems }\end{array}$ & $\begin{array}{l}\text { Collection of data required for the maintenance pro- } \\
\text { cess from business subjects and survey conduction. }\end{array}$ \\
\hline & $\begin{array}{l}\text { L1I.11. Finance man- } \\
\text { agement informational } \\
\text { systems }\end{array}$ & $\begin{array}{l}\text { Data analysis, report preparation, monitoring of the } \\
\text { implementation of the activity's indicators. }\end{array}$ \\
\hline
\end{tabular}


The two factor groups - the one of information and the one of communication means as a tool of increasing the regulatory efficiency - are also closely related. A large part of factors that influence the use of information and communication means are also influenced by the needs of business entities. The use of information systems is an important topic to both regulatory institutions, and to business, as they seek higher efficiency.

Table 3 and Table 4 represent the hierarchal classification of factors that will be used for the analysis of the factors' importance assessment (Alcaide-Muñoz et al., 2017; Anthopoulos et al., 2016; Baldwin \& Black, 2008, 2016; Baldwin et al., 2014; Benz \& Eberlein, 1999; Blockmans et al., 2014; Boer et al., 2016, 2017; Ceicyte \& Petraite, 2018; Cheng, 2014; Choi et al., 2017; Choudrie et al., 2017; Christiansson et al., 2015; González et al., 2009; Hampton, 2005; Janssen \& Voort, 2016; Juell-Skielse et al., 2017; Kersbergen \& Waarden, 2004; Klievink et al., 2016; Larsson \& Grönlund, 2016; Luna-Reyes et al., 2016; Mohan \& Parthasarathy, 2016; Mueller, 2003; Navarro-Galera et al., 2016; Scupola \& Zanfei, 2016; Urban \& Joubert, 2017; Zemanovicova \& Vasakova, 2016).

Table 4. Factors' classification on the business entities' level (created by the authors)

\begin{tabular}{|c|c|c|}
\hline Factors' group & $\begin{array}{c}\text { Primary factors of } \\
\text { evaluation }\end{array}$ & Qualities that shape the factor \\
\hline \multirow{6}{*}{$\begin{array}{l}\text { L2R. Regulatory } \\
\text { process }\end{array}$} & L2R.1. Time & Reduce time required by the controlling institutions. \\
\hline & L2R.2. Trust & $\begin{array}{l}\text { Take regulatory decisions with confidence and observe } \\
\text { the regulatory institutions' efforts to follow them. }\end{array}$ \\
\hline & L2R.3. Consultancy & $\begin{array}{l}\text { Supervisory institutions must first of all be business } \\
\text { consultants. }\end{array}$ \\
\hline & L2R.4. Competitiveness & Provide equal conditions for competition. \\
\hline & $\begin{array}{l}\text { L2R.5. Optimization of } \\
\text { the legal base }\end{array}$ & $\begin{array}{l}\text { Abolish, simplify, merge legal acts or informational } \\
\text { commitments or improve their regulation. }\end{array}$ \\
\hline & L2R.6. Purposefulness & $\begin{array}{l}\text { Research the possibilities of risk evaluation efficiency, } \\
\text { optimize the amount of data provided. }\end{array}$ \\
\hline \multirow{5}{*}{ L2K. Expenses } & $\begin{array}{l}\text { L2K.1. Coordination } \\
\text { expenses }\end{array}$ & $\begin{array}{l}\text { Coordination expenses obtained in cases when more } \\
\text { than one organization participates in the regulatory } \\
\text { process. }\end{array}$ \\
\hline & $\begin{array}{l}\text { L2K.2. Administrative } \\
\text { expenses }\end{array}$ & $\begin{array}{l}\text { Administrative and general expenses obtained by busi- } \\
\text { ness subjects that follow regulatory requirements. }\end{array}$ \\
\hline & $\begin{array}{l}\text { L2K.3. Activity's adap- } \\
\text { tation to the regulatory } \\
\text { changes }\end{array}$ & $\begin{array}{l}\text { Operational expenses of business entities while trying } \\
\text { to adapt to regulatory changes. }\end{array}$ \\
\hline & $\begin{array}{l}\text { L2K.4. Consultation, } \\
\text { training and certifica- } \\
\text { tion expenses }\end{array}$ & $\begin{array}{l}\text { Operational expenses of business entities while trying } \\
\text { to meet the obligatory certification requirements and } \\
\text { carry out consultation or training obligations. }\end{array}$ \\
\hline & $\begin{array}{l}\text { L2K.5. Functional } \\
\text { consolidation }\end{array}$ & $\begin{array}{l}\text { Processes identified and means proposed to carry them } \\
\text { out more efficiently. }\end{array}$ \\
\hline \multirow{2}{*}{ L2E. E-services } & $\begin{array}{l}\text { L2E.1. Information } \\
\text { consistency }\end{array}$ & $\begin{array}{l}\text { Impact on the population, businesses and government } \\
\text { via e-services or informational system. }\end{array}$ \\
\hline & $\begin{array}{l}\text { L2E.2. Frequency of the } \\
\text { service use }\end{array}$ & Number of service uses per given period. \\
\hline
\end{tabular}


End of Table 4

\begin{tabular}{|c|c|c|}
\hline Factors' group & $\begin{array}{c}\text { Primary factors of } \\
\text { evaluation }\end{array}$ & Qualities that shape the factor \\
\hline & L2E.3. Service cost & $\begin{array}{l}\text { The change in service provision and reception cost after } \\
\text { its digitalization. }\end{array}$ \\
\hline \multirow{3}{*}{$\begin{array}{l}\text { L2I. Informa- } \\
\text { tion and com- } \\
\text { munication } \\
\text { means }\end{array}$} & $\begin{array}{l}\text { L2I.1. E-services' } \\
\text { provision informational } \\
\text { systems }\end{array}$ & $\begin{array}{l}\text { To help simplify citizens' participation in approving } \\
\text { new rules and standards by explaining to them official } \\
\text { obligations and procedures. }\end{array}$ \\
\hline & $\begin{array}{l}\text { L2I.2. Operational in- } \\
\text { formation management }\end{array}$ & $\begin{array}{l}\text { Data analysis, report preparation, monitoring how the } \\
\text { operational indicators are implemented. }\end{array}$ \\
\hline & $\begin{array}{l}\text { L2I.3. Knowledge } \\
\text { based information } \\
\text { systems }\end{array}$ & $\begin{array}{l}\text { Make public legal acts, compile information bases, and } \\
\text { provide clear and systematic information and instruc- } \\
\text { tions that would be easily accessible to business entities. }\end{array}$ \\
\hline
\end{tabular}

After the list of factors that influence the efficiency of consolidation of the activities of regulatory institutions while implementing e-government solutions has been compiled, one may proceed to the stage of expert evaluation when multiple criteria evaluation method is applied. At this stage it is important to establish which of the factors listed are the most significant and influential where the increase of efficiency of regulatory institutions is concerned. Evaluation of the factors' significance is carried out by analyzing the case of regulatory institutions that operate in Lithuania.

\section{Research methodology}

The multiple criteria research method was chosen in order to evaluate the efficiency and complexity of the factors that influence the consolidation of activities of the regulatory institutions while implementing e-government solutions as well as seeking a more objective and higher quality result of the evaluation, this gives a reason to look for integrated and structured evaluation approaches (Ginevičius \& Ostapenko, 2015; Zavadskas \& Podvezko, 2016; Zavadskas, Turskis, Vilutienè, \& Lepkova, 2017). These evaluation methods encompass various combinations of qualitative and quantitative approaches - expert evaluation and the use of mathematical analysis. When the complete multiple criteria evaluation method is used, we create conditions for the alternative comparative analysis and for selection of such alternatives that provide the highest integrated criterion value.

The most widely applied multiple criteria evaluation methods are TOPSIS, AHP, PROMETHEE, COPRAS and ELECTRE. For further research the AHP method was chosen, because it includes a large set of possible criteria as well as evaluative aspects of both qualitative and quantitative criteria (Brunelli, 2015; Macharis, Springael, De Brucker, \& Verbeke, 2004; Saaty, 1987; Sultan, AlArfaj, \& AlKutbi, 2012). Moreover, the AHP method is widely applied for solving multiple criteria problems in such fields as model planning, concept evaluation etc.

In this research the aim of the AHP method was to establish the importance of the factors, to group them, create a hierarchical structure and in that way give experts opportunity to perform a complete evaluation. One of the main drawbacks of the AHP method is the complexity of the mathematical problem and the long process of calculation that is time 
consuming compared to other dual comparative methods (Macharis et al., 2004). In order to avoid the drawbacks of the AHP method in this research the criteria were divided into groups and in this way the set of possible criteria comparisons was reduced.

In order to take well-balanced decisions in the process of consolidation of the regulatory institutions activities it is important to make sure that the priority goals of the policy of the regulatory institutions will be accomplished, therefore when choosing multiple criteria evaluation methods, one must take into account the importance of expert evaluation and apply such methods that would help to find out preferences of the relevant people who take part in the process of decision making. In Table 5 the research process is presented, it consists of 7 stages, starting with compilation of the matrix of factors and ending with the calculation of normalized values.

Table 5. Stages of multiple criteria evaluation (created by the authors)

\begin{tabular}{|c|c|c|}
\hline Stage No. & Stage definition & Evaluation aspect \\
\hline Stage 1 & $\begin{array}{l}\text { Compilation of factors' matrix for every } \\
\text { classified factor. }\end{array}$ & $(M)=\left(\begin{array}{cccc}\frac{a 1}{a 1} & \frac{a 1}{a 2} & \cdots & \frac{a 1}{a n} \\
\frac{a 2}{a 1} & \frac{a 2}{a 2} & \cdots & \frac{a 2}{a n} \\
\cdots & \cdots & \cdots & \cdots \\
\frac{a n}{a 1} & \frac{a n}{a 2} & \cdots & \frac{a n}{a n}\end{array}\right)$ \\
\hline Stage 1.1 & Dual comparison. & $\begin{array}{l}\text { Weights are attributed to every factor } \\
\qquad\left(A_{1}-A_{n}\right)\end{array}$ \\
\hline Stage 1.2 & The Eigenvalue is found. & $B_{i j}=\frac{A_{i j}}{\sum_{i=1}^{n} A_{i j}}$ \\
\hline Stage 1.3 & $\begin{array}{l}\text { The value of proper vector is calculated } \\
\left(V_{i j}\right) \text { (AHP weight). }\end{array}$ & $V_{i j}=\frac{\sum_{j=1}^{n} B_{i j}}{n}$ \\
\hline Stage 1.4 & $J_{\max }$ is calculated. & $J \max =\sum_{j=1}^{n}\left(\sum_{i=1}^{n} \times V_{i j}\right)$ \\
\hline Stage 1.5 & $\begin{array}{l}\text { The index of values' compatibility is } \\
\text { calculated. }\end{array}$ & $C I=\frac{J \max -n}{n-1}$ \\
\hline Stage 1.6 & $\begin{array}{l}\text { The matrix factors' compatibility coef- } \\
\text { ficient is calculated. }\end{array}$ & $C R=\frac{C I}{R I} \times 100$ \\
\hline Stage 2 & $\begin{array}{l}\text { With the compatibility coefficient } \\
\text { verified, the AHP weight for every } \\
\text { factor is confirmed. }\end{array}$ & $V_{i j}=\frac{\sum_{j=1}^{n} A_{i j}}{n}$ \\
\hline
\end{tabular}


End of Table 5

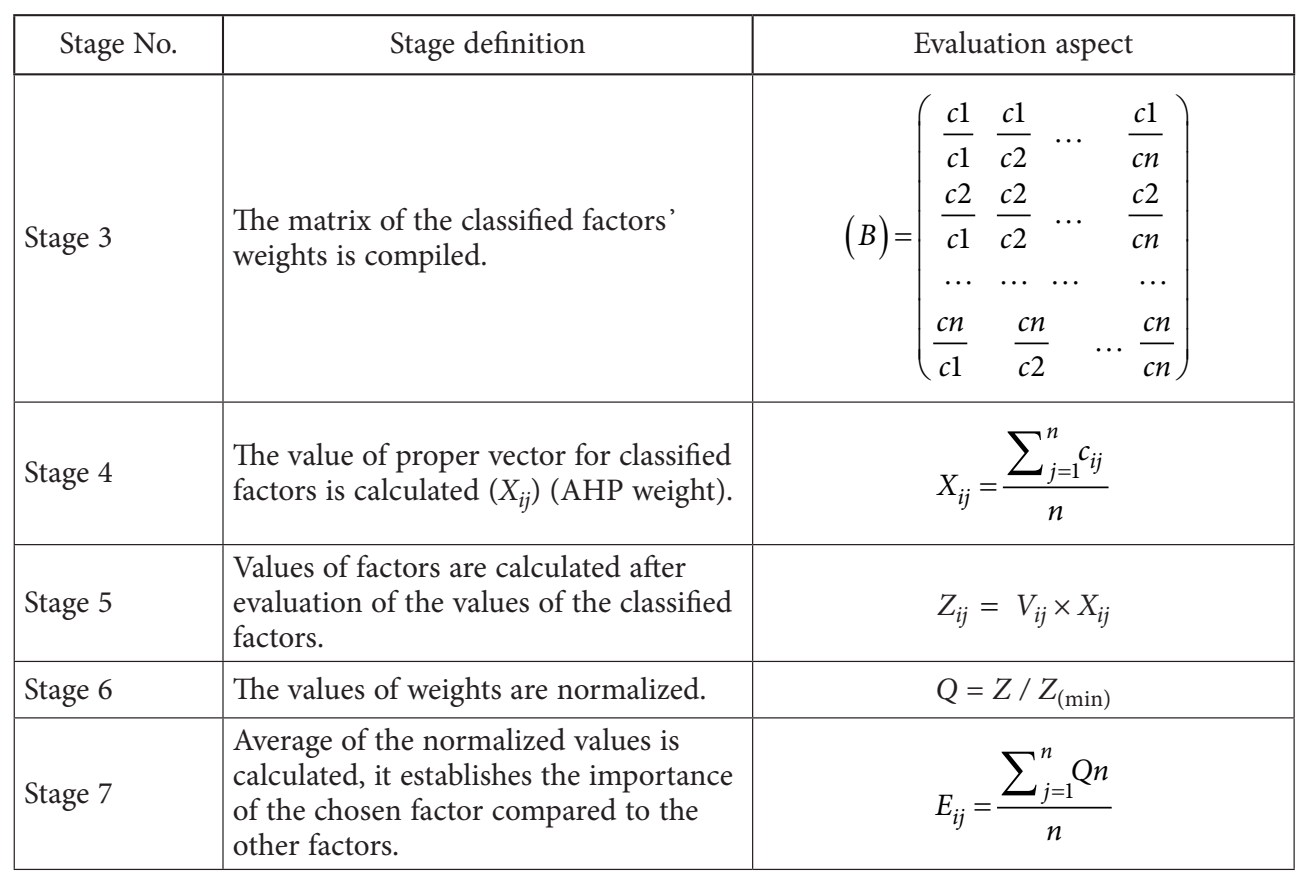

The expert evaluation was done in 2017 and it was organized in the manner of structured survey, in order to verify the compatibility of expert values and attribute weights to the factors of the regulatory institutions' level and the business entities' level. 6 experts participated in the expert evaluation: 3 experts represented the regulatory institutions' level and 3 others were from the business entities group. When choosing experts for the analysis of the factors of regulatory institutions level two selection criteria were chosen competence and not less than 10 years of experience in working the field of regulatory institutions. When choosing experts for the analysis of the factors of business entities the paramount factors were the competence of the experts and work experience in solving strategic business development issues.

\section{Research results and discussion}

In the first stage the experts of the regulatory institutions were asked to fill in the values of the factors and classified factors, and based on this data, the weight of the factors was calculated according to the AHP method, as well as Lambda max, and CI, an RI coefficient was chosen and the CR coefficient of the matrix inputs compatibility was checked.

According to the experts of regulatory institutions, the optimization of the legal base needs the most attention. The experts whose area of expertise is the legal base emphasize its shortcomings and the drawbacks of the legal acts when it comes to a more efficient regulatory work. Efficiency and purposefulness are singled out as the key factors in the attempts to affectively use the regulatory institutions' resources for coming up with a strategy. The 
factor of accountability is a complicated process, however, the experts stress that without responsibility and clear definition of regulatory system the efficiency will suffer. The factors of cooperation and information consistency as well as the factors of the institutional and functional consolidation are seen assessed as being important for inter-institutional cooperation, as they prevent provision of repetitive information and thus reduce the administrative load for business entities and the expenses for the maintenance of the regulatory system (Table 6).

Table 6. The results of the significance of the factors that influence the efficiency of the consolidation of the activities of regulatory institutions while implementing e-government solutions (the results of the expert evaluation by regulatory institutions) (created by the authors)

\begin{tabular}{|c|c|c|c|}
\hline Factor & $\begin{array}{c}\text { Signifi- } \\
\text { cance }\end{array}$ & Factor & $\begin{array}{c}\text { Signifi- } \\
\text { cance }\end{array}$ \\
\hline $\begin{array}{l}\text { L1R.2. Optimization of the legal } \\
\text { base }\end{array}$ & 70.98 & $\begin{array}{l}\text { L1I.1. Maintenance work information } \\
\text { systems }\end{array}$ & 7.40 \\
\hline L1R.5. Efficiency & 33.03 & $\begin{array}{l}\text { L1I.11. Finance management information } \\
\text { systems }\end{array}$ & 7.33 \\
\hline L1R.4. Purposefulness & 32.52 & $\begin{array}{l}\text { L1I.3. Register management informa- } \\
\text { tional systems }\end{array}$ & 6.53 \\
\hline L1R.3. Accountability & 29.07 & $\begin{array}{l}\text { L1I.8. Knowledge-based information } \\
\text { system }\end{array}$ & 6.29 \\
\hline L1R.1. Cooperation & 22.95 & $\begin{array}{l}\text { L1I.4. Document management informa- } \\
\text { tional systems }\end{array}$ & 5.96 \\
\hline L1E.1. Information consistency & 21.53 & $\begin{array}{l}\text { L1I.9. Risk management and evaluation } \\
\text { informational systems }\end{array}$ & 5.91 \\
\hline L1K.5. Institutional consolidation & 19.40 & L1K.1. Annual budget of institutions & 5.57 \\
\hline L1K.6. Functional consolidation & 13.78 & L1E.4. Frequency of the service use & 5.32 \\
\hline L1K.4. Number of active subjects & 10.44 & L1K.7. Coordination expenses & 5.24 \\
\hline L1E.5. Cost of services & 9.90 & $\begin{array}{l}\text { L1I.7. Activity's information management } \\
\text { information systems }\end{array}$ & 4.62 \\
\hline L1E.2. Segment & 9.52 & L1K.3. Number of employees & 4.10 \\
\hline $\begin{array}{l}\text { L1I.6. E-services' provision infor- } \\
\text { mational systems }\end{array}$ & 9.45 & L1K.2. Salaries and consultation fees & 2.10 \\
\hline $\begin{array}{l}\text { L1I.2. Specific informational sys- } \\
\text { tems unrelated to maintenance }\end{array}$ & 8.57 & $\begin{array}{l}\text { L1I.5. Permits and licenses accounting } \\
\text { systems }\end{array}$ & 2.05 \\
\hline L1E.3. E-segment & 7.68 & $\begin{array}{l}\text { L1I.10. Laboratory research informational } \\
\text { systems }\end{array}$ & 1.17 \\
\hline
\end{tabular}

After the experts' evaluation one may notice that business subjects consider functional consolidation, operational adaptability to regulatory changes, information consistency and e-services as the most important ones. The least important is the time that the regulatory process takes and the risk evaluation systems used by the regulatory institutions (Table 7).

Business experts emphasize the importance of reducing large expenses for the state's regulatory system and the necessity to stop providing repetitive information. Another important factor are the expenses of adaptation of operations to the regulatory changes, this factor also influences business entities and increases administrative costs. Business entities 
Table 7. The results of the significance of the factors that influence the efficiency of the consolidation of the activities of regulatory institutions while implementing e-government solutions (the results of the expert evaluation by business entities) (created by the authors)

\begin{tabular}{|l|c|l|c|}
\hline \multicolumn{1}{|c|}{ Factor } & Value & \multicolumn{1}{|c|}{ Factor } & Value \\
\hline L2K.5. Functions' consolidation & 14.37 & L2R.6. Purposefulness & 3.20 \\
\hline $\begin{array}{l}\text { L2K.3. Operational adaptability } \\
\text { to regulatory changes }\end{array}$ & 13.76 & L2K.1. Cost of coordination & 3.08 \\
\hline L2E.1. Information consistency & 8.73 & L2E.3. Cost of services & 3.04 \\
\hline $\begin{array}{l}\text { L2I.1. E-services provision infor- } \\
\text { mation systems }\end{array}$ & 7.97 & L2R.5. Optimization of the legal base & 2.93 \\
\hline $\begin{array}{l}\text { L2E.2. Frequency of the service } \\
\text { use }\end{array}$ & 5.26 & $\begin{array}{l}\text { L2I.3. Knowledge-based information } \\
\text { systems }\end{array}$ & 2.75 \\
\hline L2R.3. Consultation & 4.40 & L2R.1. Time & 2.44 \\
\hline $\begin{array}{l}\text { L2I.2. Informational systems of } \\
\text { the activity management }\end{array}$ & 4.39 & L2R.2. Trust & 2.35 \\
\hline L2R.4. Competitiveness & 3.82 & $\begin{array}{l}\text { L2I.4. Informational systems of risk } \\
\text { management and evaluation }\end{array}$ & 1.92 \\
\hline L2K.2. Administrative expenses & 3.77 & $\begin{array}{l}\text { L2K.4. Expenses for consultation, } \\
\text { training and certification }\end{array}$ & 1.87 \\
\hline
\end{tabular}

are in favor of implementing informational systems of electronic services provision, taking into account the service use frequency factor and strengthen the processes of business entities consultation as well as focus on increasing quality.

\section{Conclusions}

After the assessment of the challenges being faced by regulatory institutions it seems that there is not enough of consolidation of regulatory institutions activities to improve the quality of public services, reduce time consumption, make inter-institutional cooperation more efficient and decision-making process faster.

Based on the analysis of scientific literature, analysis of the environment of the regulatory institutions in operation and the case of the Lithuanian maintenance institutions 35 primary evaluation factors were identified. Classification of factors that determine improvement of regulatory institutions' activities was proposed taking into account the aspects of mutual interdependence of e-government and public electronic services, regulatory expenses and operations' consolidation as well as the aspects of the use of information communication means.

With the help of multiple criteria evaluation and expert evaluation methodology for the research of the consolidation of the activities of regulatory institutions' while implementing e-government solutions was prepared, and it enables one to evaluate activities of regulatory institutions by establishing the significance of various factors in every country's case.

The possibilities of the created evaluation system for assessment of the consolidation of the activities of regulatory institutions' while implementing e-government solutions were 
tested while analyzing the activities of the Lithuanian regulatory institutions. During the research differences in the opinions of regulatory institutions' experts opinion and business entities' experts' opinion were established when the experts were evaluating the significance of factors that influence the process of consolidation of the activities of regulatory institutions' while implementing e-government solutions. The experts that represent regulatory institutions consider optimization of the legal base the key factor, whereas business representatives think that simplification of institutions' consolidation and of regulatory process are much more important.

The practical significance of the research lies in the fact that factors that influence the activities of regulatory institutions have been systemized and a hierarchical classification of factors that influence the activities of regulatory institutions, which allows rational decision making when it comes to providing public services in the field of regulation, evaluate the spectrum of factors and their criteria, identify drawbacks of activities and create decisions for problem elimination. The results of the research may be used by governments of various countries for analysis of the possibilities to improve the efficiency of the regulatory institutions' activities.

The results obtained in the research are subject to certain limitations. The system proposed for assessment of the factors that influence the efficiency of the consolidation of regulatory institutions' activities while implementing e-government solutions was tested with the Lithuanian regulatory institutions. In order to be able to apply the system universally more thorough research needs to be done examining cases of other European Union countries.

Further scientific research could be done in the following fields: experimental verification of the efficiency evaluation and their applicability to in individual cases of various countries' regulatory institutions taking into account their particular features. Also, evaluation of factors that impact the efficiency of the efficiency of the consolidation of regulatory institutions' activities while implementing e-government solutions, interrelations of variables and their influence on the efficiency of consolidation.

\section{References}

Alcaide-Muñoz, L., Rodríguez-Bolívar, M. P., Cobo, M. J., \& Herrera-Viedma, E. (2017). Analysing the scientific evolution of e-Government using a science mapping approach. Government Information Quarterly, 34(3), 545-555. https://doi.org/10.1016/j.giq.2017.05.002

Anthopoulos, L., Reddick, C. G., Giannakidou, I., \& Mavridis, N. (2016). Why e-government projects fail? An analysis of the Healthcare.gov website. Government Information Quarterly, 33(1), 161-173. https://doi.org/10.1016/j.giq.2015.07.003

Baldwin, R., \& Black, J. (2008). Really responsive regulation. Modern Law Review, 71(1), 59-94. https://doi.org/10.1111/j.1468-2230.2008.00681.x

Baldwin, R., \& Black, J. (2016). Driving priorities in risk-based regulation: what's the problem? Journal of Law and Society, 43(4), 565-595. https://doi.org/10.1111/jols.12003

Baldwin, R., Black, J., \& O’Leary, G. (2014). Risk regulation and transnationality: institutional accountability as a driver of innovation. Transnational Environmental Law, 3(02), 373-390.

https://doi.org/10.1017/S2047102514000120 
Benz, A., \& Eberlein, B. (1999). The Europeanization of regional policies: patterns of multi-level governance. Journal of European Public Policy, 6(2), 329-348. https://doi.org/10.1080/135017699343748

Blanc, F. (2013). Inspection reforms: why, how, and with what results. Retrieved from https://www.oecd. org/regreform/Inspection reforms - web -F. Blanc.pdf

Blendinger, G., \& Michalski, G. (2018). Long-term competitiveness based on value added measures as part of highly professionalized corporate governance management of German DAX 30 corporations. Journal of Competitiveness, 10(1), 5-20. https://doi.org/10.7441/joc.2018.02.01

Blockmans, S., Hoevenaars, J., Schout, A., \& Wiersma, J. M. (2014). From subsidiarity to better EU governance: a practical reform agenda for the EU. CEPS Essay, 10, 1-13.

Boer, Y., Arendsen, R., \& Pieterson, W. (2016). In search of information: investigating source and channel choices in business-to-government service interactions. Government Information Quarterly, 33(1), 40-52. https://doi.org/10.1016/j.giq.2015.11.010

Boer, Y., Pieterson, W., Arendsen, R., \& Dijk, J. (2017). Towards a model of source and channel choices in business-to-government service interactions: a structural equation modeling approach. Government Information Quarterly, 34(3), 434-456. https://doi.org/10.1016/j.giq.2017.07.002

Brunelli, M. (2015). Introduction to the analytic hierarchy process. Cham: Springer. https://doi.org/10.1007/978-3-319-12502-2

Carroll, P., \& Head, B. (2010). Regulatory reform and the management of intergovernmental relations in Australia. Australian Journal of Political Science, 45(3), 407-424. https://doi.org/10.1080/10361146.2010.509310

Ceicyte, J., \& Petraite, M. (2018). Networked responsibility approach for responsible innovation: perspective of the firm. Sustainability, 10(6), 1-15. https://doi.org/10.3390/su10061720

Cheng, K. T. (2014). From public management reform to regulatory governance. International Journal of Management and Innovation, 6(1), 94-105. Retrieved from http://web.a.ebscohost.com/ehost/ pdfviewer/pdfviewer?vid=0\&sid=874a9f03-b42e-4239-b9c6-de3e0d6b1ebf\%40sessionmgr4006

Choi, H., Park, M. J., \& Rho, J. J. (2017). Two-dimensional approach to governmental excellence for human development in developing countries: combining policies and institutions with e-government. Government Information Quarterly, 34(2), 340-353. https://doi.org/10.1016/j.giq.2017.03.002

Choudrie, J., Zamani, E. D., Umeoji, E., \& Emmanuel, A. (2017). Implementing E-government in Lagos State: understanding the impact of cultural perceptions and working practices. Government Information Quarterly, 34, 646-657. https://doi.org/10.1016/j.giq.2017.11.004

Christiansson, M. T., Axelsson, K., \& Melin, U. (2015). Inter-organizational public e-service development: emerging lessons from an inside-out perspective. In Electronic Government: Proceedings of the14th IFIP WG 8.5 International Conference, EGOV 2015 (pp. 183-196). Cham: Springer. https://doi.org/10.1007/978-3-319-22479-4_14

Cledou, G., Estevez, E., \& Soares Barbosa, L. (2018). A taxonomy for planning and designing smart mobility services. Government Information Quarterly, 35(1), 61-76. https://doi.org/10.1016/j.giq.2017.11.008

Foremny, D., Sacchi, A., \& Salotti, S. (2017). Decentralization and the duration of fiscal consolidation: shifting the burden across layers of government. Public Choice, 171(3-4), 359-387. https://doi.org/10.1007/s11127-017-0441-0

Gil-Garcia, J. R. (2012). Towards a smart State? Inter-agency collaboration, information integration, and beyond. Information Polity, 17(3, 4), 269-280. https://doi.org/10.3233/IP-2012-000287

Ginevičius, R., \& Ostapenko, A. (2015). A quantitative evaluation of the company environment for the formation of its effective expansion strategy. Intellectual Economics, 9(2), 130-137. https://doi.org/10.1016/j.intele.2016.02.004 
González, M. M., Perelman, S., \& Trujillo, L. (2009). Tracking the stepwise effects of regulatory reforms over time: a 'back-door' approach. Applied Economics, 41(2), 211-218.

https://doi.org/10.1080/00036840600994294

Hampton, P. (2005). Reducing administrative burdens: effective inspection and enforcement. Norwich: HM Treasury.

Janssen, M., \& Voort, H. (2016). Adaptive governance: towards a stable, accountable and responsive government. Government Information Quarterly, 33(1), 1-5. https://doi.org/10.1016/j.giq.2016.02.003

Juell-Skielse, G., Lönn, C. M., \& Päivärinta, T. (2017). Modes of collaboration and expected benefits of inter-organizational E-government initiatives: a multi-case study. Government Information Quarterly, 34, 578-590. https://doi.org/10.1016/j.giq.2017.10.008

Kersbergen, K. V., \& Waarden, F. V. (2004). "Governance” as a bridge between disciplines: cross-disciplinary inspiration regarding shifts in governance and problems of governability, accountability and legitimacy. European Journal of Political Research, 43(2), 143-171.

https://doi.org/10.1111/j.1475-6765.2004.00149.x

Klievink, B., Bharosa, N., \& Tan, Y. H. (2016). The collaborative realization of public values and business goals: governance and infrastructure of public-private information platforms. Government Information Quarterly, 33(1), 67-79. https://doi.org/10.1016/j.giq.2015.12.002

Larsson, H., \& Grönlund, A. (2016). Sustainable eGovernance? Practices, problems and beliefs about the future in Swedish eGov practice. Government Information Quarterly, 33(1), 105-114. https://doi.org/10.1016/j.giq.2015.11.002

Layfield, C. (2014). Opportunities in E-Government utilizing cloud computing: an Eu perspective. International Journal on Information Technologies \& Security, 2, 2-25.

Luna-Reyes, L. F., Picazo-Vela, S., Luna, D. E., \& Gil-Garcia, J. R. (2016). Creating public value through digital government: lessons on inter-organizational collaboration and information technologies. In The Proceedings of 49th Hawaii International Conference on System Sciences (HICSS) (pp. 28402849). IEEE. https://doi.org/10.1109/HICSS.2016.356

Macharis, C., Springael, J., De Brucker, K., \& Verbeke, A. (2004). PROMETHEE and AHP: the design of operational synergies in multicriteria analysis: strengthening PROMETHEE with ideas of AHP. European Journal of Operational Research, 153(2), 307-317.

https://doi.org/10.1016/S0377-2217(03)00153-X

Maegli, M., \& Jaag, C. (2013). Competition and the social cost of regulation in the postal sector. In Center-for-Research-in-Regulated-Industries (CRRI) 20th Conference on Postal and Delivery Economics (pp. 294-305). St. Helier, Jersey.

Maegli, M., Jaag, C., Koller, M., \& Trinkner, U. (2011). Postal markets and electronic substitution: implications for regulatory practices and institutions in Europe. In Center-for-Research-in-Regulated-Industries (CRRI) 18th Conference on Postal and Delivery Economics (pp. 109-122). Zurich, University of Zurich. https://doi.org/10.4337/9781849805964.00013

Maume, P. (2013). The financial markets authority: a model example for regulatory consolidation? New Zealand Universities Law Review, 25(3), 26. Retrieved from https://papers.ssrn.com/sol3/papers. cfm?abstract_id=2448184

Miyazaki, T. (2018a). Examining the relationship between municipal consolidation and cost reduction: an instrumental variable approach. Applied Economics, 50(10), 1108-1121. https://doi.org/10.1080/00036846.2017.1352077

Miyazaki, T. (2018b). Internalization of externalities and local government consolidation: empirical evidence from Japan. Empirical Economics, 54(3), 1061-1086.

https://doi.org/10.1007/s00181-017-1242-5 
Mohan, A. K., \& Parthasarathy, B. (2016). From hierarchy to heterarchy: the state and the Municipal Reforms Programme, Karnataka, India. Government Information Quarterly, 33(3), 427-434. https://doi.org/10.1016/j.giq.2016.05.007

Mueller, D. C. (2003). Public choice III (3rd ed.). New York: Cambridge University Press. https://doi.org/10.1017/CBO9780511813771

Navarro-Galera, A., Alcaraz-Quiles, F. J., \& Ortiz-Rodríguez, D. (2016). Online dissemination of information on sustainability in regional governments. Effects of technological factors. Government Information Quarterly, 33, 53-66. https://doi.org/10.1016/j.giq.2015.12.003

Saaty, R. W. (1987). The analytic hierarchy process-what it is and how it is used. Mathematical Modelling, 9(3-5), 161-176. https://doi.org/10.1016/0270-0255(87)90473-8

Scupola, A., \& Zanfei, A. (2016). Governance and innovation in public sector services: the case of the digital library. Government Information Quarterly, 33(2), 237-249. https://doi.org/10.1016/j.giq.2016.04.005

Sultan, A., AlArfaj, K. A., \& AlKutbi, G. A. (2012). Analytic hierarchy process for the success of egovernment. Business Strategy Series, 13(6), 295-306. https://doi.org/10.1108/17515631211286146

Urban, B., \& Joubert, G. C. D. S. (2017). Multidimensional and comparative study on intellectual capital and organisational performance. Journal of Business Economics and Management, 18(1), 84-99. https://doi.org/10.3846/16111699.2016.1255990

Zavadskas, E. K., \& Podvezko, V. (2016). Integrated determination of objective criteria weights in MCDM. International Journal of Information Technology \& Decision Making, 15(2), 267-283. https://doi.org/10.1142/S0219622016500036

Zavadskas, E. K., Turskis, Z., Vilutienė, T., \& Lepkova, N. (2017). Integrated group fuzzy multi-criteria model: case of facilities management strategy selection. Expert Systems with Applications, 82, 317331. https://doi.org/10.1016/j.eswa.2017.03.072

Zemanovicova, D., \& Vasakova, L. (2016). Independent regulatory institutions in the global economy. In 16th International Scientific Conference on Globalization and its Socio-Economic Consequences (pp. 2498-2504). Rajecke Teplice, Slovak Republic, University of Zilina. 